\title{
Dark Room aqui: um ritual de escuridão e silêncio
}

\author{
María Elvira Díaz Benítez
}

\begin{abstract}
resumo Entre os diversos espaços destinados a encontros sexuais ocasionais, analiso neste artigo a forma como se estrutura o ritual de interação dentro do dark room em uma boate de socialização de homens que exercem práticas homoeróticas. Elaboro uma aplicação da teoria dos atos da fala de J. L. Austin em um contexto onde são os gestos, os movimentos, a localização no espaço, entre outros signos corporais, os atos performativos que não só dizem, mas fazem algo. How to do things without words? Como etnografar no silêncio? Que dizem os gestos? Como se fazem coisas com os gestos? Qual é seu poder "mágico"? Qual é a energia que está contida neles assim como nas palavras? Utilizo para este fim consideraçóes teóricas que na antropologia têm desafiado a preeminência da linguagem e do sentido da visão na prática etnográfica e no exame das formas como os coletivos organizam suas experiências.
\end{abstract}

palavras-chave Antropologia ritual. Corpo. Etnografia. Atos performativos. Silêncio.

Na parte alta da porta, um cartaz branco leva escrito em letras maiúsculas de cor negra duas palavras: "Dark room". A seu lado, uma flecha vermelha complementa a mensagem levando escrito em seu interior: "Aqui". Ambos os signos, palavras e flecha, indicam a localizaçáo de um lugar, mas, no contexto em que aparecem, funcionam melhor como um convite. Sempre há pessoas do lado de fora olhando - inquietamente - em direçáo à porta, deixando que sorrisos e gestos denunciem a curiosidade por atravessar essa espécie de "umbral". Apesar de a flecha vermelha ter estado ali desde 1992, para algumas pessoas o caminho que indica continua sendo enigmático, enquanto para muitos funciona como uma espécie de "lugar-templo", cheio de signos, repleto de possibilidades.

Quando atravessam a porta, aqueles que esperavam ansiosamente que fosse aberta e aqueles que sucumbiram diante da curiosidade, encontram-se com uma luz clara que pende do teto e ilumina outros cartazes. O primeiro adverte: "A casa não se responsabiliza por objetos perdidos. Favor manter nos armários". O segundo sentencia: "Está proibido o uso de drogas neste estabelecimento, os infratores estarão sujeitos às penalidades previstas pela lei”. Ninguém se detém na leitura dos avisos com cuidado, quiçá porque já sabe o que dizem, talvez porque náo lhe interesse obedecer. A luz que pende do teto ilumina um corredor estreito, com chão úmido, que termina em um saláo quadrado. Ali também termina a luz abrindo passo para uma penumbra leve através da qual se vislumbram sombras, corpos que entram e saem, que estacionam em algum lugar do espaço ou se perdem de vista quando se internam na escuridáo. Quando a penumbra se torna mais espessa e já não permanecem rastros daquela luz que iluminava o corredor, começa a segunda sala: o quarto do breu.

Eu tenho entrado. Inúmeras vezes. Na primeira vez me localizei na penumbra, perto do corredor. Dali recebi uma linha tênue de luz que permitiu que meus olhos se acostumassem à escuridão e pudessem perceber, com certa clareza, sombras e corpos se movimentando ao meu redor. Poucos minutos depois, notei que alguns rapazes que estavam no mesmo lugar que eu começaram a sair intempestivamente, $\mathrm{e}$ supus que podiam estar intimidados com a minha presença. Decidi ficar ali um tempo mais. No entanto, os rapazes continuaram saindo. 
Pensei que eu poderia estar infringindo algum código de interação daquele espaço de socialização - quase exclusivamente - masculino. Então, percebi que minha primeira incursão no ritual da escuridáo e do silêncio tinha sido infeliz.

Durante várias noites em que visitei a boate fiquei do lado de fora, exatamente na porta que separa o dark room do balcáo. Assim podia ver as pessoas que entravam e as freqüências relativas ao ingresso. Algumas semanas depois, quando acreditei compreender as normas que orientavam a participação no ritual, decidi entrar e localizar-me em uma parte um pouco mais escura, justamente no lugar que divide simbolicamente a penumbra do breu. Nessa ocasião demorei duas horas no dark room, e dessa vez nenhum dos rapazes saiu de lá precipitadamente. Comecei a entender que o problema que enfrentei na minha primeira tentativa náo tinha sido entrar no dark room, mas ficar na penumbra onde os olhares podiam alcançar-me através daquela claridade sutil.

As tentativas têm continuado. Tenho caminhado entre a escuridão e a penumbra, tenho ficado quieta. Tenho agüentado o calor e guardado silêncio, tenho bebido guaraná e cerveja, tenho jogado o copo no chão, tenho tentado participar. No entanto, não tenho me masturbado, nem tenho masturbado ninguém, não tenho feito sexo oral em nenhum dos rapazes nem tenho sido penetrada, não tenho efetuado todos os gestos que estruturam o ritual, nem pronunciado as pouquíssimas palavras que o complementam.

$\mathrm{O}$ mainstream antropológico tem estabelecido como principal método etnográfico a observação participante. Mas, para mim, a experiência do dark room me impede de participar, de fato. Aliás, nem sequer me permite observar nitidamente. O dark room é um espaço masculino e minha presença ali, de alguma maneira, é uma espécie de transgressão. Uma transgressão que não é irrevogável e mas negociável, que não impede que as coisas aconteçam como acostumam acontecer, porém, ainda assim, não sou ali uma pessoa autorizada, se considerarmos os termos de Austin (2003 [1962]). Embora seja certo que toda observaçáo implica, em si, uma participaçáo, acredito que meu esforço etnográfico tenha se constituído, principalmente, em uma observação acompanhante.

Existe também na antropologia mainstream e na prática etnográfica uma tendência a valorar o referencial falado. Tem-se ponderado o poder e a importância do que é dito, o significado das palavras dentro de um contexto cultural e a força que estas têm para transformar sociedades.

Malinowski ensina que a linguagem é nossa principal ferramenta, sem ela "o conhecimento de qualquer cultura é incompleto" (1935, p. 21). Para Leach, o ritual em comunidades primitivas é um complexo que reúne palavras e açôes: "Não é o caso de que as palavras são uma coisa e o rito é outra. A expressão das palavras é, em si mesma, um ritual" (2000 [1966], p. 407). Tambiah (1968) fala das "expressōes mágicas". Destaca o poder criativo das palavras, a maneira como os objetos ganham vida por meio delas, como criam efeitos ao estar relacionadas à realidade social onde são pronunciadas, e as maneiras como incidem sobre o mundo (o que para Malinowski é a função pragmática da linguagem). Herzfeld (2003) chama a atenção sobre as intenções daquilo que é dito, pergunta-se se existe uma analogia completa entre o que se quer dizer e aquilo que efetivamente é dito.

Apesar destes autores, entre muitos outros, entenderem a importância do que é dito, estes, simultaneamente, desafiam seu poder exclusivo na prática etnográfica. $\mathrm{O}$ mesmo Malinowski (1935) ensina a "desconfiar" das palavras dos nativo; para ele, a linguagem não é necessariamente sinônimo ou análogo ao pensamento humano. Com isto, convida a pensar em como 
se usam os gestos para designar metaforicamente algo. Para Leach, gestos e movimentos também são rituais. Tambiah (1985), por sua vez, confronta a institucionalização da linguagem na prática etnográfica se perguntando como palavras e gestuais têm sentidos que não são obrigatoriamente concomitantes ao seu sentido referencial. Em seu estudo sobre mantras de exorcismo (Tambiah, 1968), chama a atenção para a necessidade de se entender o significado dos mantras, não só através do entendimento de palavra por palavra, nem apenas a partir de uma análise das formas verbais como se fossem uma categoria diferenciada, mas mediante as seqüências nas quais as palavras são ditas, em relação ao seu sentido emocional e ao seu caráter sagrado objetivado em cançôes, oraçóes ou bençãos. Herzfeld (2003) desafia o referente falado explicando que, apesar de existir uma prática coletiva e um engajamento no ritual, não necessariamente aquilo que está sendo dito é totalmente entendido por seus agentes.

Já em Stoller (1966) encontramos que esse desafio é levado até as últimas conseqüências. Referindo-se ao papel dos griots do Sahel e mais especificamente à prática de praise-naming dos griots entre os Wolof do Senegal, o autor explica que, muito além das palavras, o que produz transformações mágicas em quem as escuta é a emoção que ocasiona o som das palavras:

São sopros e vibraçôes de ar, constituídos e moldados pelo corpo e as motivaçóes do orador, as quais tocam e influenciam fisicamente ao destinatário. Assim, o efeito do louvor de um griot que o informante tem sobre seus destinatários é equivalente ao efeito do vento sobre o fogo (Irvine 1980 apud Stoller 1966, p. 177).

Stoller debate também sobre o fato de que a prática etnográfica tem priorizado aquilo que se pode ver, deixando de lado análises baseadas em dimensôes como o tato, o olfato, o gosto e a escuta, enfim, os sentidos a partir dos quais muitas sociedades organizam suas experiências e constroem seus mundos. Em sua belíssima etnografia, intitulada Sound and things (Sons e coisas) e feita em Songhay (Tillaberi, Nigéria), o autor concentrou sua atençấo no som do violino godji e no tambor gasi, "o godji chora", sublinhando que através desse lamento falam os ancestrais, o poder de suas vozes une os vivos com seu passado, são: “[...] poderes sonoros que podem trazer a chuva, erradicar pestilências e prevenir epidemias" (Stoller, 1966, p. 178).

Em um contexto sociocultural como o de Songhay, não escutar o mundo é aprender pouco sobre ele. Se para eles o som é o transporte dos espíritos, pergunta-se Stoller: Como limitar a análise à visão? Como reduzir o som do godji às anotaçôes de página? ${ }^{1}$

Neste artigo, pretendo me unir aos esforços de diversos antropólogos em desafiar a preeminência do que é falado na análise do ritual. A posição de Stoller acerca da maneira como as pessoas se conectam aos sons, através de sua própria orientação de mundo, serve-me de inspiração para fazer o seguinte questionamento etnográfico: Como "o povo" do dark room orienta sua experiência a partir do silêncio? Qual a relaçáo entre o silêncio e os significados culturais da interação na escuridão? Como fazer etnografia no e do silêncio?

Se em muitas sociedades e coletivos utilizase a visão como maneira de conhecer e apreender o mundo, no dark room a visão é só um dos elementos que compóem o ritual de interação. Nesse contexto, o tato é privilegiado. As palavras são comumente substituídas pela linguagem corporal: as coisas que se desejam dizer e fazer, explicitam-se mediante gestos, poses e localização dos corpos no espaço. Se no restante da boate os códigos de relacionamentos permitem o contato verbal, no dark room os contatos

1. Criticando a noçáo de textualismo de Clifford Geertz. 
começam com os toques, no ato de apalpar e se deixar ser apalpado pelos outros. Permitir ser acariciado ou impedir uma carícia é um método mais eficaz que as palavras para começar ou terminar uma aproximação. Em poucas palavras, são o silêncio, a escuridáo, os gestos, $\mathrm{o}$ tato $\mathrm{e}$ a alteração das emoções que, muito além das palavras, preenchem o ritual de significados.

Já mencionei que minha participação neste ritual privilegiou a escuta e a observação, na medida em que aproveitei as probabilidades que a escuridão me ofereceu, diante da impossibilidade de colocar em funcionamento alguns dos meus outros sentidos, especialmente o tato. No entanto, como já advertiu Herzfeld (2003), não existe a obrigação de participar no ritual como "ele é", mas pode-se vivê-lo de diversas formas. Então, seguindo a sugestão de Stoller, tentei colocar para funcionar minha percepção por meios sensoriais. Além da visão, tentei me deixar penetrar pelo silêncio como ele fez com o som do godji, tentei sentir a escuridão e inclusive, tentei me alterar com cerveja, NOvA SCHIN, para ver se dessa maneira conseguia compreender o significado do dark room através do meu próprio corpo.

\section{How to do things without words: um uso da teoria do ato de fala de J. L. Austin}

Expressöes performativas, diz Austin (2003 [1962]) são aquelas que mediante sua emissão realizam uma ação e não podem ser concebidas como um mero "dizer algo".

Por sua vez, ao pronunciar as palavras correspondentes do performativo, é importante como regra básica que outras coisas ocorram bem. Ou seja, que existam as circunstâncias adequadas para poder dizer que a ação tem sido executada com sucesso (precisa-se de um apropriado "contexto da situaçấo", nos termos de Malinowski). Para ser adequado, um procedimento deve incluir a emissão de certas palavras por parte de certas pessoas e em certas circunstâncias. Aliás, deve gerar certo efeito, ou seja, precisa que sobrevenha uma dada conduta correspondente. Se alguma ou várias destas pautas não se cumprem, a expressão performativa será, de um ou outro modo, infeliz.

$\mathrm{O}$ ato da fala, segundo o autor, está caracterizado por um esquema tríplice: Ato locucionário, ilocucionário e perlocucionário. $\mathrm{O}$ ato locucionário é a expressáo mesma que possui significados. Quando alguém diz algo, é importante distinguir o ato de dizê-lo, que consiste em emitir certas palavras com determinada entonação e acentuação e que tem fixado um dado sentido de referência. Isto é chamado por Austin dimensão locucionária do ato lingüistico. Ilocucionário é o ato que exercemos ao dizer algo: prometer, afirmar, advertir, insultar, parabenizar, ameaçar etc. Consiste em provocar a compreensão do significado e a força da locução. Seu efeito reside na força que possui ao dizer algo. Já o perlocucionário consiste em lograr efeitos pelo fato de dizer algo: intimidar, assombrar, convencer, ofender etc.

Embora no dark room o silêncio não seja absoluto, ele é privilegiado. As palavras são substituídas por gestos e movimentos algumas vezes seqüenciais. Austin explica que os atos que possuem o caráter geral de serem rituais ou cerimoniais (apostar, transferir o domínio de uma coisa, por exemplo) podem ser realizados por meios não verbais. Nossos atos ilocucionários (advertir, ordenar, dar, protestar, pedir desculpas, por exemplo) podem ser efetuados sem o uso das palavras e mediante gesticulaçôes. Da mesma maneira, a perlocução, ou seja, os efeitos ou respostas à ilocução, também podem ser logrados de maneiras não verbais. 
Apesar de Austin (2003 [1962]) ressalvar que nossos atos de fala podem incluir o gesto (cf. p. 60, 163, 164, 166), Grimes (1996, p. 283) enfatiza o fato de que esta teoria tem sido majoritariamente aplicada em contextos que incluem formas verbais:

A teoria dos atos da fala poderia ser de pouco uso em ritos caracterizados principalmente por silêncio ou movimentos. O ritual é uma forma cultural mais complexa que a fala, porque pode incluir todas as variantes da fala, enquanto a fala náo pode incluir todas as variedades de ritual. [...] A teoria dos atos da fala, desenvolvida além de análises lingüísticas filosóficas, é usualmente aplicada só a fenômenos verbais. Aqui podemos estender sua aplicaçáo ao ritual, a um fenômeno performativo.

Levando em conta que "A tipologia austiniana é aplicável não só a coisas ditas nos contextos rituais, mas também a coisas feitas neles" (Grimes, 1996, p. 283), tentarei aqui analisar o ritual (ou os rituais) do dark room prestando atenção nas expressóes performativas contidas nos gestos e movimentos e na força destas expressóes; nos atos ilocucionários efetuados mediante trejeitos, senhas, acenos, piscadas e posturas do corpo, e nas respostas ou efeitos que se obtêm por meios igualmente não verbais. Em poucas palavras, analisarei: o que nos dizem os gestos? Como se fazem coisas com os gestos? Que gestos dizem que coisas? Qual o poder "mágico" dos gestos? Qual é a energia que está contida neles da mesma forma que há energia contida nas palavras?

Por outro lado, no caso do ritual de escuridão e silêncio, cumpre-se o anunciado por Leach (2000 [1966]): o ritual é um ato voluntário porque quem participa nele, encontra um sentido. No entanto, dentro do dark room nem todas as pessoas participam da mesma forma, perseguindo os mesmos objetivos, motivo que leva ao acontecimento de múltiplos infortúnios ${ }^{2}$.

Tambiah (1985) já disse que, embora nos rituais haja um conjunto de regras aparentemente invariáveis, existem também nos atores interesses relacionados a uma expansão de significado. Desta maneira, tentarei examinar as formas como se criam situações infortunadas, ou seja, momentos nos quais se erra na execução do ritual, efetuam-se procedimentos que não devem aplicar-se, executam-se procedimentos que não podem ser aplicados, momentos onde a cerimônia não se efetua completamente, ou se realizam atos não autorizados. Por exemplo: não receber uma carícia, não aceitar uma aproximação, não permitir um tipo específico de relacionamento sexual, entender um gesto de maneira errada, efetuar de forma equivocada um gesto, localizar-se em um lugar incorreto no espaço etc.

Da mesma maneira como me pergunto pela eficácia dos gestos, é interessante observar quais pessoas (autorizadas, diria Austin 2003 [1962]) estão em uma posição de efetuar o ritual de maneira mais eficaz e quais estão mais propensas a infortúnios.

\section{Ritual de "pegação" em dois episódios}

Tentar descrever o ritual de interaçáo que acontece no dark room é como tentar relatar minuciosamente um show da orquestra sinfônica. O narrador poderia deter-se nos detalhes da melodia interpretada pelo piano, pelo violino ou pelo trombone de forma singular ou poderia tentar explicar as cadeias de sons de todos os instrumentos que, ao soarem simultaneamente, compõem uma mesma harmonia. O dark room é um lugar onde sucedem várias

2. Na última parte deste artigo, elaborarei uma explicação mais detalhada daquilo que Austin chamou "doutrina dos infortúnios". 
situaçôes distintas ao mesmo tempo, onde não existe uma norma acerca do número de pessoas que podem participar do ritual e onde nem todos possuem as mesmas intençôes quanto à própria participação. Da mesma maneira como em uma orquestra o contrabaixo segue uma partitura escrita em clave de Fá, o xilofone uma em clave de Sol e os instrumentos participam de uma mesma melodia, mas cada um deles conservando um momento e uma forma diferenciada, no dark room todos participam guiados por seu próprio desejo, mas, no entanto, reconhecendo e obedecendo as expressóes e os movimentos a partir dos quais podem compor o ritual maior.

$\mathrm{O}$ dark room tem seu próprio ritmo, que se compóe dos ritmos individuais de seus participantes. Tem uma temporalidade que todos reconhecem, que, por sua vez, é determinada não só pelos agentes, mas pelo ritmo da boate como um todo.

Descreverei em seguida o ritual de "pegação" que ocorre no dark room. Apresento as diversas situações que o compóem, ressaltando as seqüências a partir das quais o ritual se estrutura. Ao terminar a descrição, elaborarei um exame cuidadoso dos detalhes em relação à teoria dos atos de fala de Austin, tendo como foco as expressões performativas contidas nos gestos, sua força ilocucionária, sua resposta perlocucionária e os infortúnios.

\section{[A PENUMBRA]}

À meia-noite abrem-se a porta. Os clientes da boate começam a entrar um a um, às vezes de dois em dois ou em pequenos grupos. $\mathrm{Na}$ maioria das vezes, ficam de início na penumbra, encostando-se nas paredes. Alguns acendem um cigarro ou acabam de fumar o cigarro que traziam desde a pista de dança. Outros rapidamente terminam de beber a cerveja que segundos atrás solicitaram no balcão ou a bebem mais devagar enquanto passam a mão lentamente sobre a virilha. Tanto os que se apressam em acabar os tragos de cerveja quanto os que saboreiam seu conteúdo parcimoniosamente, jogam o copo branco no chão para liberar as mãos.

Sem saírem do lugar, observam os corpos que entram e os que se movimentam ao seu redor, sabendo que são observados por aqueles que estão no breu. A luz do corredor permite que se vislumbrem as silhuetas, suas formas, seus contornos, seus traços. No entanto, impede a distinçáo dos rostos e a apreciaçáo dos semblantes.

Através do tom cinza do ambiente, os rapazes da penumbra podem efetuar um primeiro critério de seleçáo do homem ou dos homens com os quais desejam começar um intercurso sexual ou uma "brincadeira", modo como eles mesmos chamam o ato de se acariciar sem transformar esse jogo erótico em uma transa propriamente dita. Ao mesmo tempo, o fato de estarem na penumbra lhes permite que sejam selecionados pelos outros.

De um momento para outro, um ou vários rapazes que se acariciavam, tocando a virilha, abrem o zíper, tomam o pênis e o colocam para fora da calça, acariciam-no cuidadosamente sem sair do lugar em que haviam "estacionado". Alguém que entra ou que simplesmente permanece em silêncio, encostado na parede, aproxima-se de um homem que já está com o pênis ereto, estende a mão em direção ao genital e o acaricia. Se o outro homem náo o impede, afastando-o com um gesto ligeiro e leve, rapidamente começa a masturbá-lo, aproximando seu corpo e unindo-se ao outro em um abraço.

Enquanto isso acontece, numa das esquinas da penumbra, um homem se coloca de costas, desce a calça deixando as nádegas descobertas, $\mathrm{e}$ aproxima as mãos da genitália, ficando na posição de quem está urinando. No entanto, todos 
sabem o que ele está fazendo: suas mãos estão concentradas em uma carícia lenta que não pretende se transformar em masturbação. Outro rapaz se aproxima dele até que seus braços se rocem, observa-lhe o pênis durante vários segundos, estica sua mão até tocá-lo, mas antes de conseguir fazê-lo, o homem seminu dá meia volta e se coloca em outro lugar da penumbra.

Ao mesmo tempo, um rapaz que observava a cena se aproxima do homem que ainda acaricia o próprio pênis. Passa-lhe a mão pelo rosto, tenta beijá-lo. O outro esquiva-se delicadamente, virando o rosto da esquerda para a direita, impedindo que seus lábios se unam. No entanto, permite que aquele desconhecido lhe acaricie o pênis. $\mathrm{O}$ rapaz insiste em beijá-lo e, enquanto o masturba, aproxima a mão do outro para seu próprio pênis, sinalizando que também deseja ser masturbado. Segundos depois ambos se unem em um beijo intenso.

$\mathrm{O}$ casal que, alguns minutos antes, estava se abraçando, agora separam seus corpos. Caminham poucos passos até a parte mais escura da penumbra. Um deles, aquele que iniciou a aproximaçáo, abaixa-se à altura do pênis do outro, aproxima sua boca e começa a lambê-lo.

No corredor, dois rapazes param alguns centímetros antes de entrar na penumbra. Com um gesto rápido, um deles aspira cocaína em um papelzinho de cor prata. Oferece ao seu amigo, que também cheira e depois guarda o papel em um dos bolsos da calça. Entram. Várias pessoas os observaram, mas ninguém faz comentários. Este não é um evento extraordinário, apesar de o consumo de drogas na boate não ser completamente freqüente e ser feito, preferencialmente, nos banheiros. Ambos os rapazes param debaixo da linha de luz e, minutos depois, "internam-se" no breu.

Uma moça entra de mãos dadas com um rapaz. Pára na penumbra. Faz um comentário ao ouvido do acompanhante, ambos sorriem e, alguns minutos depois, saem do lugar.
Um rapaz, que durante todo o tempo só ficou observando, sai da penumbra e atravessa o corredor, esquivando-se das poças de água e de cerveja que se misturam no chăo completamente molhado. Minutos depois, entra novamente com um copo plástico na mão cujo conteúdo seguramente é NOVA SCHIN, a única bebida alcoólica que se distribui de maneira liberada dentro da boate. $\mathrm{O}$ garoto se coloca em outro ponto da penumbra e apenas observa, sem permitir que alguém comece uma aproximação erótica.

Dois rapazes se aproximam do casal que fazia sexo oral. Um deles os observa. Acende seu telefone celular perto do intercurso oral criando uma fileira fina de luz de tom verde, que lhe permite observar a cena com detalhe. $\mathrm{O}$ outro rapaz passa uma de suas mãos pelas nádegas de quem está sendo "chupado"3, mas este lhe impede continuar a caricia mediante um gesto rápido e delicado.

De repente, um rapaz alto, de corpo sarado e cabelos molhados entra na penumbra. Veste uma camisa branca colada ao corpo, que ressalta seus músculos peitorais e abdominais, e uma calça de jeans azul apertada nas nádegas, pernas e virilha. Ele não se encosta às paredes, não faz movimento nenhum. Fica naquele lugar do saláo perto da luz do corredor onde a penumbra ainda não é muito espessa. Um rapaz se aproxima e lhe oferece um cigarro, que ele não aceita. O rapaz se afasta e, com um movimento de cabeça, indica para um de seus amigos que dirija seu olhar em direção do novo visitante do dark room, aquele de corpo sarado percebe que está sendo observado.

Pouco depois, um grupo de três rapazes entra na penumbra, colcando-se atrás do novo "centro das atenções". Um deles pára justamente ao seu lado e começa a acariciar seu pró-

3. Usarei neste artigo vários termos nativos. No circuito pesquisado uma palavra utilizada frequentemente para denominar o sexo oral é "chupação". 
prio pênis sem tirá-lo da calça. Acelera a carícia enquanto fuma um cigarro com a outra mão. O homem de camisa branca e jeans azul olha para o pênis de seu "vizinho", observando-lhe o corpo inteiro. Sem poder distinguir claramente o aspecto do rosto, coloca a mão no pênis do rapaz e, segundos depois, os dois se dirigem até a parede lateral mais escura da penumbra.

O garoto que só observava sai procurando por mais cerveja e volta rapidamente. Tropeça com outro que, rompendo o silêncio, grita: "Joáo! João está aqui?”. Ninguém lhe responde.

Do lado de fora, embaixo da flecha vermelha, um dos funcionários da boate distribui gratuitamente preservativos em uma cesta que traz escrito: "fique esperto". De um momento para outro, um rapaz atravessa rapidamente o corredor, chega à penumbra e toma bruscamente em seu braço um dos garotos que começava a participar de uma masturbação: "Já chega!", diz, e precipitadamente o empurra para fora do saláo.

Com o passar do tempo, a penumbra começa a ficar mais cheia de gente. Muitos corpos se encostam às paredes, o espaço do centro se enche de homens que observam, se tocam, fumam e se acariciam. Alguns entram no breu, outros saem pelo corredor. $\mathrm{O}$ ar começa a esquentar, escutam-se respiraçóes cada vez mais aceleradas. Nesse momento, saio para buscar uma cerveja. Volto rapidamente. Os ventiladores que pendem do teto parecem insuficientes. Observo alguns rapazes secarem o suor com as mãos, outros se secam com suas camisas que, nessa altura da noite, muitos deles já não vestem mais.

\section{[O BREU]}

No espaço onde a penumbra acaba, uma outra dinâmica se apodera do lugar. A escuridão fica mais densa impedindo que a visão seja utilizada como o sentido a partir do qual se possa organizar a experiência. Se na penumbra observar é importante como um primeiro critério de seleção de parceiro, no breu o essencial é não ser observado. Se a penumbra permite que se enxergue ligeiramente os corpos e se imagine as partes impossíveis de se ver, no breu é necessário imaginar o corpo todo ou permitir que o tato seja o sentido que induza a descoberta das formas do corpo alheio com o qual se começa um intercurso sexual.

Não quero dizer com isto que naquele lugar a escuridão seja completa, total. A escuridão na sala do breu é similar à sensação de ver onde náo se vê, como quando apagamos a luz do quarto antes de dormir e não encontramos nossa cama. No entanto, alguns segundos depois, quando nossos olhos se acostumam à escuridão, conseguimos percebê-la entre as sombras mesmo que não possamos distinguir nitidamente sua aparência. Desta maneira, é na sala do breu onde os outros sentidos - tato, olfato e paladar - começam a operar com mais efetividade do que a visão. Diferentemente da penumbra, onde todas as pessoas permanecem encostadas nas paredes, no breu, os corpos se espalham no espaço. Enquanto alguns se posicionam nas laterais, outros caminham, transitam de um lado para o outro da sala, circulando sempre para náo tumultuar o centro e impedir o passo daqueles que vêm logo atrás.

Os que permanecem quietos, na maioria das vezes têm seus corpos apontando para frente, e mesmo que isso ocorra, no breu, são poucos os que se colocam de costas. Geralmente todos aqueles que se encostam às paredes $\mathrm{e}$ que ainda náo tenham começado uma aproximação com outros rapazes, masturbam-se ou acariciam seu pênis sem obrigatoriamente tirálo da calça. Ao mesmo tempo, outros garotos caminham, alguns se acariciam, outros descem as calças para baixo da virilha deixando o pênis e as nádegas descobertos. Aqueles que se movimentam no espaço, dirigem as mãos aos 
corpos que tropeçam e dos que estão estáticos. As mãos procuram os peitorais, as nádegas, mas, especialmente os genitais. A maioria deles enfoca seu desejo nos pênis e é a partir dessa localização explícita que se inicia ou se impede uma interação sexual.

A partir da meia-noite, quando se abre a porta do dark room, o breu começa a se encher, recebendo os clientes da casa. Mas é a partir de uma hora da manhã que o local realmente começa a "ferver". No meio da efervescência, um rapaz passa ao meu lado. Eu estou quieta encostada na parede. Passa a mão no meu peito, e rapidamente descobre que sou mulher e, portanto, pelo menos naquele momento, que não sou objeto de seu desejo. Continua caminhando.

Outro rapaz entra no saláo e atravessando a penumbra diz em voz alta: "Vinte centímetros chegou!" e entra na escuridão, unindo-se à massa de gente que circula de um lado para outro. Alguns minutos depois, dois rapazes entram no dark room, um deles aponta outro com o dedo indicador, rompendo o silêncio ao falar em voz alta: "Essa aí voltou mais doida de Londrina!". Outros rapazes observam quem foi apontado e continuam em suas posiçóes sem fazer nenhum comentário.

Um garoto está em uma das paredes laterais acariciando o pênis. Um dos meninos que transita pelo centro do breu dirige a mão para ele e começa a acariciá-lo. O primeiro rapaz aceita a carícia e o aproxima de seu corpo. Entâo, passa a mão pelas nádegas do outro, que ao mesmo tempo em que aceita a carícia, tenta beijá-lo. Beijam-se. Minutos depois, o garoto que começou a aproximaçáo se vira de costas com a intenção de que ambos os corpos fiquem posicionados de frente em relação às demais pessoas da sala. Abaixa a calça à altura dos joelhos e, por meio de movimentos ligeiros, é penetrado. Quase todas as vezes que presenciei penetraçóes, estas eram feitas com os corpos na posição descrita acima.
Naquele horário, quase duas horas da madrugada, várias pessoas do breu levam adiante relaçôes sexuais que incluem a penetração. É aí que silêncio é quebrado, não por palavras, mas por gemidos e respiraçôes aceleradas que preenchem o ambiente com uma sensação etérea, na qual se mesclam calor, umidade, cheiro de cerveja e fluidos corporais, zumbido dos ventiladores, enjôo causado pelo álcool, movimento dos corpos que se roçam e interpenetram, além da música que, vinda do balcão, no dark room soa como um barulho distante.

As relações em que ocorre a penetração chamam sempre a atenção das pessoas presentes, que se aproximam para enxergar de perto ou tentar começar um Baco. ${ }^{4}$ Como observar no breu não é fácil, alguns dos rapazes "trasladam" a penumbra acendendo relógios, celulares, isqueiros ou fósforos. Aqueles que não se interessam por observar, mas por participar, fazem carícias nos dois homens envolvidos na transa, caso eles permitam ou não a intervenção de terceiros.

Muitas vezes, as carícias são aceitas. Então, unem-se ao duo outros rapazes que váo chegando um a um até formarem uma turma. Estes interagem tocando os pênis e as nádegas dos outros, penetrando e sendo penetrados, masturbando-se ou praticando a felação entre si. Por meio de sussurros, às vezes se dizem coisas como: "quer dar?”, "Pô, chupa aí!", "Pô estou a fim de comer!", "Gostoso!".

Tenho escutado algumas pessoas dizerem em voz alta: "Chegou a vagabunda!", "Um metro está aqui!", entre outras frases do mesmo estilo.

Para alguns rapazes o dark room é um lugar de passagem dentro da boate, no qual só se entra

4. Baco é uma palavra utilizada em diversos ambientes gays cariocas. O pesquisador Luiz Felipe Rios (2004, p. 94) define baco como "uma forma condensada de bacanal; refere-se ao que, em geral, se conhece como práticas sexuais (masturbação, felação, sexo anal etc.), onde duas ou mais pessoas estão envolvidas". 
após ter permanecido tempo suficiente na pista de dança, no balcão ou na sala de sinuca, uma vez a boate começa a atender seu público a partir das $22 \mathrm{~h}$, e só duas horas depois abre a porta do quarto escuro. Por este motivo, quando os rapazes entram no dark room, já passaram por diversas experiências durante a noite. Neste sentido, o dark room, e especialmente o breu, rompem com a estrutura que guia o ritual de pegaçáo do restante da boate e particularmente com a dinâmica que se experimenta na pista de dança.

Percebi pela etnografia que a pista de dança funciona como uma passarela e um laboratório de performances que possui certas regras em relação ao uso do espaço e do corpo muito diferentes daquelas do dark room. Na pista, os garotos que possuem corpos malhados são quase exclusivamente os únicos que tiram suas camisas e geralmente ficam junto às esquinas do saláo. Os modos de se vestir são similares: calças jeans azuis ajustadas às pernas e camisas sem mangas, de malha, de cor branca ou preta.

No gueto gay ${ }^{5}$ estes rapazes são chamados de barbie. O estilo "barbie" é um dos mais desejados no nível erótico e representa uma das estéticas gays mais aceitas nestes circuitos. É pouco comum encontrar alguém considerado barbie fazendo pegação no breu. Se entrar no dark room, geralmente está acompanhado por outra pessoa com quem já começou uma paquera ou uma aproximação corporal na pista de dança.

Também nos cantos da pista de dança se localizam os homens que estão sós (é estranho encontrar alguém que não esteja acompanhado dançando no centro da pista). Estes homens

5. A palavra gueto referese aos indivíduos homossexuais, "entendidos" ou conhecedores das dinâmicas dos "mundos gays" e seus locais de socialização como, por exemplo, boates, saunas, cinemas, parques. Gueto, como explica Perlongher (1987) é uma área nômade, que se desloca com a população envolvida e que não possui um limite geográfico fixo, dependendo da movimentação das redes. geralmente circulam pelo restante da boate e, na pista, sua interaçáo se limita a observar, aproximar-se de um ponto de abastecimento de cerveja, falar com o DJ ou com algum dos funcionários. Às vezes, os garotos solitários se dirigem ao saláo de espelhos e dançam observando a si mesmos. É comum que, em um momento avançado da noite, aqueles que continuam solitários na pista de dança e desejam começar um intercurso sexual, dirijam-se ao dark room.

Além da diversão, a dança permite aos rapazes se mostrarem atraentes, chamarem a atenção do sujeito de seu desejo. A pista é uma espécie de vitrine onde as pessoas podem mostrar-se utilizando seu visual, seus corpos e os passos de dança como mecanismos para atrair e encontrar parceiros. Enquanto na pista é importante observar esse outro em quem se deposita o desejo, no breu a pegação fica "nas mãos" da escuridão, "pega-se no sorteio", como muitos dizem.

No entanto, essa dança tem suas normas e limites: foi masculinizada, é uma manifestação mais da masculinização da imagem gay, obedece a certas técnicas corporais generificadas. Quem dança e se importa com essa "norma" tem que prestar atenção aos limites dos movimentos corporais para não se afastar dos cânones valorizados. Quem transgride essa performance e "se solta muito", ou faz um uso do corpo que não seja basicamente masculino, corre o risco de ser acusado de exdrúxulo, ridículo, por ter passado do ponto na extravagância e na excentricidade. Então, frente à possibilidade de encontrar um parceiro, a dança deve ser suficiente atraente para chamar a atenção, mas prudente para náo estragar a possibilidade de pegação. A paquera, quer se esteja dançando ou não, começa com os olhares, dificilmente com os toques ou sarraçóes ${ }^{6}$. Olhar é o ponto-chave:

6. A palavra sarração faz parte do vocabulário do circuito. Rios (2004, p. 81) a define como o ato de "esfregar-se, roçar as partes erógenas em busca de excitação sexual". 
quem está interessado no outro o olha sutilmente, em intervalos, durante os quais dá goles em seu copo de cerveja ou faz algum comentário ao pé do ouvido de quem está perto. Olha insistentemente, mas guardando algum limite para não parecer desesperado. Quando a outra pessoa percebe que está sendo alvo de observação, pode corresponder olhando quem a observa de forma recíproca ou descartá-la, desviando o olhar para outro lugar da pista, ou náo cruzando os olhares, novamente, com quem começou o ritual de pegaçáo. Uma vez que ambos demonstrem interesse na interação, inicia-se uma troca de palavras ou dançam alguma música juntos. Se o interesse progredir, podem dirigir-se às quinas da pista onde a interação passa do verbal aos contatos corporais, como o beijo e a sarração. Os espelhos que pendem do alto das paredes, além de servirem para admirar os outros dançando e a si mesmo, servem como mecanismo para cruzar olhares e começar paqueras, compartilhar sinais e gestos que indiquem gosto ou desinteresse. A oralidade na pista de dança é muito mais valorizada do que em lugares de pegaçáo como parques ou dark rooms, e nem sempre uma aproximação, mesmo que desejada, culmina em sexo.

No dark room, ao contrário, a intenção na maioria das vezes é explícita. Não conseguir levar adiante uma relação sexual, ou não conseguir masturbar ou ser masturbado, fazer sexo oral ou recebê-lo pode ser pensado nesse contexto como um infortúnio ${ }^{7}$. De fato, a densidade da escuridáo garante que o ritual possa ocorrer da maneira como ocorre. A escuridão não faz parte da estrutura do ritual, a escuridão é a sua própria estrutura.

Assim, o breu, para aqueles que dispensam completamente a penumbra, parece ser um mecanismo para encontrar um parceiro sexual sem ter que passar pelos olhares seletivos presentes

7. À exceção das pessoas que entram no dark room com intençóes voyeuristas. nos espaços iluminados. Ou seja, pessoas que na penumbra, na pista de dança ou no restante da boate não teriam "sucesso" ou teriam menos possibilidades de arranjar um encontro íntimo, podem no breu se relacionar sexualmente com pessoas que quiçá em outro contexto as excluiriam, ou podem se relacionar com aqueles que se dirigem ali pelos mesmos motivos, porque estáo sendo rechaçados pela aparência, cor ou estilo: geralmente os considerados muito feios, muito negros, muito gordos, muito velhos, muito efeminados ou alguma imbricação destas características. A escuridão produz anonimato e este admite a produção de novos códigos de interação cuja mediação direta é o segredo. Pessoas que possuem gostos por indivíduos que não são os mais aceitos no mercado erótico ou por práticas sexuais como "dar", que hierarquicamente se situa abaixo de "comer", podem no dark room encontrar essa liberdade proporcionada pelo anonimato.

O dark room, por outro lado, possui uma temporalidade que está influenciada pela temporalidade da boate como um todo. Da meianoite às quatro horas, as coisas costumam acontecer da maneira anteriormente descrita variando apenas em relação ao número de participantes e na intensidade referida aos estados emocionais e às sensaçôes causadas pelo calor, os cheiros, a multidão, o cansaço, a dança, a festa no restante da casa e os estados alterados de consciência pelo consumo de bebidas alcoólicas e drogas, em menor escala.

A sala da penumbra, com o passar das horas, muda de características. Quando o breu se encontra completamente abarrotado, as coisas que acontecem ali quase exclusivamente (como as penetrações), deslocam-se também em direção à penumbra, ocasionando uma homogeneização das açôes dentro do espaço total.

Quatro horas da manhã é um momento liminar: representa um deslocamento de um período temporário e relativo para uma outra 
situação. Nessas alturas da madrugada, o tempo da boate está terminando e o dark room sofre movimentaçôes. Algumas das pessoas que tinham permanecido a maior parte da noite ali, saem querendo aproveitar as últimas horas na pista de dança ou para beber os últimos copos de cerveja. Vários daqueles que permaneceram na penumbra ou no breu, e que não haviam se relacionado da maneira desejada no princípio, apressam-se em começar um intercurso que satisfaça seus desejos e intençôes. Igualmente, vários daqueles homens que durante sua permanência na boate náo tiveram "boa sorte" na pegação ou que desejavam se relacionar com outras pessoas, entram no dark room para "pegar as sobras", expressão que escutei pejorativamente e que se refere às relaçóes que se dão na escuridão nas altas horas da madrugada, indicando-as como últimas possibilidades de intercursos.

Entre $4 \mathrm{~h} 45$ e 5h, um dos funcionários da boate acende a luz do quarto, eu diria que de forma intempestiva. Notei que, apesar de costumeiro, isto sempre causa surpresa às pessoas que ali estão, creio que pelo fato de que no dark room o tempo parece correr em um ritmo mais lento do que no restante da boate, quiçá pelas sensaçóes causadas pela escuridão ou ainda pelas carícias íntimas e pelo silêncio compartilhado.

A luz apenas dá um tempo para as pessoas se ajeitarem. Aqueles que não estâo completamente vestidos arrumam a roupa em seu devido lugar. A luz impede vários deles de continuar praticando a penetração, felação ou beijo. Todos saem dali e se dirigem a outros lugares da boate, já que ela fechará suas portas, aproximadamente, meia hora depois.

Algumas das relaçóes que se estabeleceram na escuridão continuam no balcão da casa ou na pista de dança com conversas, troca de números telefônicos ou beijos. Alguns casais saem juntos da boate imediatamente quando a luz é acesa. Outros se separam embaixo da flecha vermelha fazendo de conta que nunca se conheceram.

\section{O poder dos gestos para dizer e para fazer}

[...] E é que o gesto náo pode ser considerado como uma expressáo do indivíduo, como uma criação sua [...] nem sequer pode ser considerado como seu instrumento; pelo contrário, são os gestos os que nos utilizam como seus instrumentos, seus portadores, suas encarnaçóes.

A imortalidade, Milan Kundera.

Se concordarmos com Milan Kundera, podemos entender que o gesto possui agência e é ele quem usa a nós próprios, seres humanos, como ferramentas a partir das quais se aciona algo. A partir deste ponto de vista, o gesto não diz, o gesto $f a z$, sendo uma expressáo do tipo performativo.

Austin (2002 [1962]), de alguma maneira, concorda com Kundera. Para ele, as expressōes performativas são aquelas que, mediante sua pronunciação, realizam uma ação e não apenas uma descriçãa. Sendo estas expressóes possíveis de se realizar não somente por meios verbais, mas também mediante os gestos. A tipologia austiniana permite lidar com aquelas coisas ditas, que não são ditas por meio de palavras, e estender a análise às coisas/atos que, em um contexto ritual, correspondem a um fenômeno performativo.

No dark room, os gestos que os indivíduos efetuam são essenciais para estruturar as relaçóes; por meio deles se organizam formas particulares de negociação e distribuição dos papéis que permitem realizar o ritual satisfatoriamente. Por isso, têm uma força performativa e "ilocucionária" formal: um ato gestual marca formalmente o começo de uma interação, delineia seu desenvolvimento e igualmente determina seu fim. 
$\mathrm{Na}$ escuridão nada ou poucas coisas são pronunciadas: os signos que transitam são determinados pelo contexto da situação, pertencem a uma natureza distinta das palavras (silêncio, movimentos, localizaçôes, senhas, toques, corpo). Estes signos são compartilhados na situação da pegação e só ali fazem sentido. As pessoas que participam do ritual de pegação no dark room sabem perfeitamente como manipular os signos, conhecem o poder que os signos têm para expressar vontades e criar açôes, existindo uma manipulação ciente deles e nada arbitrária, contradizendo assim Saussure (1994 [1916]).

Jakobson (1968 [1960]) chama a atenção sobre a forma como os signos são manipulados de maneira intencional para fazer o mundo e como estes podem ser usados como meios de comunicação de mensagens. Esta função metafórica dos signos foi definida por Jakobson como a função poética e metalingüística. Quero sublinhar aqui como essa função metafórica dos gestos, pensando em Jakobson, tem relação com a força ilocucionária que caracteriza a análise de Austin. Já tenho mencionado que a ilocução consiste em provocar a compreensão do significado, só que esses significados no dark room também possuem uma força metafórica que, como conseqüência do conhecimento que os agentes têm do funcionamento dos signos, são compreendidos e manipulados.

Ao invocar um mantra de exorcismo, Tambiah (1968) diz que não há ignorância nem ingenuidade dos nativos, eles sabem quais signos são signos, quais palavras servem para exorcizar os demônios, qual é o poder das palavras e como elas atuam em domínios que não são os nossos. No dark room aqueles signos que pertencem ao discurso da comunicação não verbal e que são manipulados intencionalmente têm força ilocucionária porque suscitam respostas e têm força metafórica porque podem remitir a uma mensagem que não é somente referencial.
Alguns dos signos/gestos-chave desta etnografia, como localização no espaço, beijar, acariciar o pênis, focar o desejo no pênis, ter a nádega descoberta etc., fazem algo acima de dizer algo e nesse fazer alguns de seus significados conduzem a metáforas. Ao analisar os gestos ou qualquer outra expressão, ensina Austin, é necessário observá-los não de forma isolada, mas em relação ao contexto em que se desenvolvem, aos procedimentos e as relaçóes envolvidas. Seguindo esta sugestáo, interessame agora explicar os significados desses gestos e sua força ilocucionária para entender como as dinâmicas que suscitam organizam aquela experiência ritual.

No breu as pessoas costumam andar ou permanecer encostadas às paredes. Aqueles que se encontram encostados às paredes estão de frente, às vezes se masturbam, às vezes apenas se acariciam, às vezes só observam, mas sempre estấo de frente. Esta localização do corpo, esse "estar de frente" no dark room significa que a pessoa não deseja começar o intercurso sexual sendo acariciado em suas nádegas e que possivelmente não desejaria exercer o papel de passivo sexual.

As pessoas que se movimentam pelo espaço, ao mesmo tempo em que vão tateando ( $\mathrm{e}$ testando) os corpos que encontram no caminho, vão sendo tateadas e testadas pelos outros. Ao caminhar, estes expóem tanto suas nádegas, quanto seu genital ao contato alheio. Embora isso não queira dizer que todos os que caminham estejam obrigatoriamente dispostos a serem os passivos sexuais, sugere que eles permitiriam que esse tipo de interaçáo ao menos fosse tentada.

Se alguém efetua o ato ilocucionário de colocar a mão na nádega de quem caminha e este o permite, então o primeiro poderá compreender que pode começar uma relação erótica na qual ele será o penetrador. Igualmente, masturbar-se e acariciar o pênis é um claro ato 
ilocucionário que convida os outros a interagirem - pelo menos em princípio - de uma maneira muito específica: mediante o "uso" do pênis. Pelo contrário, se uma pessoa nega a possibilidade a outrem de acariciar seu pênis, isto pode significar que não existe interesse em começar uma aproximaçáo com o sujeito em particular, que deseja ser acariciado e possivelmente penetrado, ou que náo há interesse em penetrar. A elucidaçáo do significado do gesto depende de outros atos ilocucionários e perlocucionários complementares.

Tenho descrito que a maioria das pessoas dirige as mãos aos pênis dos outros localizando seu desejo diretamente ali. Contudo, este ato, paradoxalmente, é independente da intençáo de distribuir as atitudes passivo/ativo; por isso acredito haver metáfora no uso dos signos. Tocam-se os pênis como primeira forma de aproximação porque assim se estruturou a participação ritual, porque é um passo a seguir (quase obrigatório) que legitima a permanência no espaço e no ato. Inclusive para aquelas pessoas que não estão interessadas em masturbar, fazer sexo oral ou serem penetradas, sua participação os empurra a interagir indireta ou parcialmente com o genital de outro ou que outros interajam (pelo menos olhando) seu genital, inclusive, sem tirá-lo da calça.

Gestos ilocucionários como os descritos anteriormente em uma negociação sexual dependem de outros atos ilocucionários e perlocucionários para a efetivação do ritual. Ou seja, algumas expressōes ilocucionárias não terminam até que o outro, gestualmente, responda positiva ou negativamente à ilocução. Finnegan (1969) chama a atenção sobre como o intercâmbio de atos ilocucionários é, de muitas formas, análogo ao ato de dar e receber um presente, questão que nos remete a Mauss (1974) para quem a dádiva gerada pelos presentes é uma maneira de reconhecer e manter relaçóes sociais. Assim, no dark room a organização ritual depende da troca de expressões performativas.

Um exemplo destas negociações são os beijos. Ao tentar beijar alguém se espera que esse outro aceite. Uma vez que ambos aceitam se beijar, geralmente começa uma relação de dois e assim é normalmente entendido pelos outros. Nos bacos, ao contrário, nem sempre as pessoas se beijam, a boca fica mais para outro tipo de interaçóes: o sexo oral, por exemplo.

No contexto da escuridáo, a localizaçáo no espaço também diz e faz algo. Descrevi que algumas pessoas se localizam nos cantos e algumas nas paredes laterais. Geralmente quem deseja ter uma relação exclusivamente de casal, onde as carícias são muito íntimas (como a penetração) permanecem nos cantos, preferencialmente naqueles mais escuros. Desta maneira, evitam ser interrompidos por outras pessoas que poderiam desejar participar no interlúdio. De fato, todos reconhecem que quem está nos cantos náo pretende participar de um baco. Pelo contrário, é nas paredes laterais onde os bacos acontecem, os participantes sabem que estão expostos a interferências.

Do mesmo modo, realizar uma penetração na penumbra é também uma expressão com força ilocucionária que geralmente recebe como resposta a aproximaçáo de muitos outros que tentarão participar observando ou iniciando um baco.

Mencionei também que na maioria das relaçôes sexuais com penetração ambos os corpos, ativo e passivo, colocam-se de frente à multidão. Esta localização também faz algo, permite a quem está sendo penetrado manter o controle da situação, ou seja, saber quem o está penetrando (na medida das possibilidades que permite a escuridáo). Ao mesmo tempo lhe permite ter livre seu pênis para a possível aproximação de um terceiro.

De forma geral, os gestos conformam um estilo de comunicação indispensável neste tipo 
de contexto de pegação. Para alguns rapazes, a gestualidade é a contrapartida do uso das palavras que se relega preferencialmente a situações nas quais as interaçôes se dão com pessoas conhecidas ou com pessoas pelas quais se sente algum afeto. $\mathrm{O}$ gesto funciona no dark room porque ali a intenção, majoritariamente, não reside em conhecer o outro, ao contrário, a composição mesma se baseia em seu desconhecimento $^{8}$.

\section{Os infortúnios do dark room}

Austin (2003 [1962]) explica que ao pronunciar as palavras correspondentes à expressão performativa é necessário, como regra geral, que outras coisas aconteçam bem para que se consiga dizer que a ação foi executada com sucesso. Se uma das convençôes que compóem a expressão não cumpre os requisitos, não se diz que a expressão é falsa, mas infortunada. Austin chamou de doutrina dos infortúnios às coisas que podem sair mal durante tais expressōes.

No geral, tais regras, segundo Austin (2003 [1962], p. 56), supóem um procedimento convencional aceito, que possua um efeito ajustado e que inclua - como expliquei anteriormente - a emissão de certas palavras, por

8. Escrevo a palavra majoritariamente porque não é possível generalizar em se tratando de intençóes e propósitos de participação no ritual. Mesmo que muitos opinem que náo seja viável começar um namoro a partir de um encontro no dark room e que ali entrem para arranjar uma relaçâo sexual casual, é necessário não esquecer a dimensão das projeçóes ideais de alguns deles. Mesmo tendo relaçốes sexuais ocasionais nestes espaços, muitos rapazes compartilham a idéia de uma ética conjugal, desejam encontrar uma pessoa para se relacionar e estabelecer um comprometimento, um namoro. O gueto, mesmo se tratando de um espaço de vínculos impessoais como o dark room, representa, para vários, o lugar onde se pode achar um parceiro ideal. parte de certas pessoas, em circunstâncias adequadas. Além disso, o procedimento deve se realizar por todos os participantes de forma correta, em todos seus passos. Naqueles procedimentos que requerem que as pessoas que os efetuam possuam certos pensamentos ou sentimentos e que estáo dirigidos a que ocorra uma conduta correspondente dos participantes, precisa-se que tais participantes possuam tais pensamentos e sentimentos e que estejam animados para conduzir-se da forma adequada, comportando-se efetivamente em sua oportunidade. A transgressão, de uma ou várias destas normas, causará o infortúnio da expressão.

Austin sublinha os seguintes casos de infortúnios: Desacertos ou atos intentados, mas nulos que por sua vez se dividem em: i) Apelaçôes ruins ou atos não autorizados presentes quando náo existe um procedimento ou quando este procedimento não pode valer da forma em que se tentou, aplicando-se mal. ii) Execuçóes ruins ou atos afetados presentes quando o procedimento existe e é aplicável à situação, mas falha na execução do rito criando atos viciados ou atos inconclusos.

O outro tipo de infortúnio é chamado de abusos ou atos pretendidos, mas ocos, isto é, aqueles onde o ato é realizado sem os sentimentos e sem os pensamentos necessários para sua efetuação. Sendo assim, são considerados insinceros.

Ronald Grimes (1996) opina que a análise dos infortúnios, proposta por Austin, deve considerar o contexto ou situação social como um todo e não as palavras soltas. Deve também ser adicionada a psicologia do ritual, ou seja, aqueles abusos que se podem inferir pelos tons de voz, modos gramaticais e gestos.

É importante destacar que nem todas as expressôes performativas, nem todos os atos rituais estão expostos a estas formas de infortúnio. $\mathrm{O}$ dark room não é exceção a esta regra. Os infortúnios que acontecem ali pertencem, em 
sua maioria, ao tipo dos desacertos (com suas apelaçôes e execuçôes ruins), sendo os abusos muito menos freqüentes.

Contudo, há um tipo de infortúnio que se apresenta no dark room que bem poderia pertencer a uma categoria em que se reúnam ambos: desacertos e abusos. Tenho indicado que no breu as coisas que náo se desejam fazer se explicam mediante gestos, os quais todos compreendem e que não dão margem a atitudes de violência. Não obstante existam, muito eventualmente, atos que têm gerado experiências de violência na escuridáo e que, embora tenham sido menos freqüentes do que poderiam (considerando o contexto da situação) têm ocorrido e sido lembrados pelas pessoas e têm conseguido, de alguma maneira, mudar seus comportamentos.

Refiro-me aos roubos. Esse procedimento é facilitado por um contexto caracterizado pela escuridão, $\mathrm{o}$ anonimato e a multidão, mas obviamente não faz parte das normas do ritual, afastando-se das expectativas da cerimônia. A partir deste ponto de vista, poderíamos dizer que o roubo é um infortúnio relativo a um ato não autorizado, segundo Austin. Poderíamos dizer também que o roubo é o que Grimes (1996, p. 285) chamou de infortúnio Nonplay, isto é, um procedimento que náo existe dentro das convençôes do ritual. Por outro lado, o roubo é também um abuso do tipo das insinceridades. Espera-se que quem entra no dark room tenha pensamentos e sentimentos sinceros de relacionar-se sexualmente com outros homens sem aproveitar aquela situação para furtar.

As situaçóes em que têm acontecido roubos ocasionaram mudanças nos comportamentos: as pessoas tentam ingressar ao dark room sem seus pertences de valor, especialmente, sem levar carteiras nos bolsos da calças. Dentro da boate circula pouco dinheiro porque, como expliquei antes, a cerveja, água e refrigerante são de distribuição liberada. Contudo, algumas pessoas durante o transcurso da noite saem e se dirigem para a porta da boate para comer churrasquinho, cachorro-quente ou caldo de mocotó, ou à portaria para comprar cigarros, chicletes ou balas de menta. Também compram fichas para a mesa de totó e para a sinuca, ou compram batatas fritas ou frango à passarinho no balcão.

Há sessenta armários à disposição do público, número insuficiente nas noites que em que entram aproximadamente mil clientes. Por este motivo, são poucas as pessoas que usam os armários. Alguns deixam seus pertences guardados ali antes de entrarem no dark room, outros os deixam aos cuidados de amigos ou entram com eles na escuridão, conscientes do perigo de serem furtados.

Outros tipos de infortúnios, certamente os mais comuns, relacionamse com as execuçöes ruins dos atos rituais, especialmente os que geram atos inconclusos ou Hitches em termos de Grimes (1996, p. 286). Refiro-me àqueles atos muito corriqueiros no breu e na penumbra, como não aceitar a carícia de uma pessoa que com ela pretende começar um intercurso sexual, ou aceitar a aproximaçáo desse outro, mas não consentir com alguns de seus pedidos, como fazer sexo oral, ser penetrado ou mesmo ser beijado.

É importante considerar que existem pessoas mais autorizadas do que outras para se "dar bem”. Existe uma preferência por pessoas de aparência atraente, de corpos que despertam o desejo erótico dos participantes do rito. Portanto, é muito mais comum que sejam as pessoas antagônicas ao padrão de beleza amplamente aceito que mais encontram impossibilidades para concluir a cerimônia. Não obstante, estes tipos de infortúnios no dark room sáo passageiros. Aquelas pessoas que são rejeitadas por outro ou por algum grupo, minutos após podem mudar o jogo, pois a dinâmica do ritual lhes permite, inclusive, concluir seu ato com outro 
ou outros participantes, e serem eles mesmos quem, posteriormente, impedem a aproximação de um terceiro. Igualmente, estas pessoas consideradas feias ou não atraentes, estão propensas a sofrer mais infortúnios na penumbra do que no breu, uma vez que para eles dispensar a penumbra é uma estratégia de levar adiante o rito satisfatoriamente.

Os rituais denominados por Grimes (1996, p. 285) de Flaws, cujos procedimentos se empregam incorretamente ou de forma vaga ou mediante fórmulas não explícitas, acontecem também no dark room, embora com menos freqüência do que os de tipo inconcluso. Um exemplo são as pessoas que ingressam ao dark room pela primeira vez. Embora estes possam ter referências prévias sobre as formas como os gestos recriam expressões performativas, sua gestualidade "novata", "tímida" ou uma inadequada localização no espaço podem criar mal entendidos. Os gestos dos novatos ou iniciados, ou inclusive os gestos dos "outsiders" (pessoas muito bêbadas, muito excêntricas ou ignorantes da linguagem gestual), podem ser vistos como exagerados ou improcedentes, impedindo-lhes, portanto, uma correta participação no ritual.

Da mesma maneira, as mulheres no dark room, mesmo executando efetivamente os movimentos, gestos e localizaçôes que legitimam o rito, tendem a ser pessoas consideradas como inadequadas ao contexto cerimonial, fato pelo qual podem estimular infortúnios do tipo misapplication (Grimes, 1996, p. 285).

Grimes (1996, p. 287) chama de contagion às situaçóes nas quais o rito transborda seus próprios limites. $\mathrm{Na}$ descrição da interação na penumbra, mencionei o episódio de um homem furioso que tirou bruscamente um outro de uma interação, puxando-o pelo braço. Não tenho certeza de que contagion seja a categoria mais adequada para denominar atos como os ciúmes. Não obstante, acredito que os ciúmes são situaçóes que ultrapassam as intençôes do ritual como um todo. De qualquer forma, fica a dúvida: se o ritual maior se compóe das intençôes individuais de seus participantes, cabe nele a possibilidade de que alguns homens ingressem ao dark room com o propósito de despertar ciúmes em seus parceiros. Neste caso, participar do ritual seria um ato ilocucionário que teria como resposta ou perlocução justamente a manifestação de ciúmes.

\section{As palavras que rompem o silêncio: sua força performativa}

Embora no dark room impere o silêncio, existem algumas palavras que valem a pena serem contempladas por sua força performativa. Austin chama a atenção sobre as açôes que ocasiona a linguagem, contrapondo-se à metodologia que tem atribuído um caráter privilegiado aos enunciados de tipo descritivo. Expressóes performativas como, por exemplo: "prometo te devolver o livro amanhâ", ditas em certas circunstâncias, executam uma ação, no caso, a ação de prometer.

No dark room têm lugar as enunciaçôes de expressōes performativas com qualidade de anunciar ou notificar algo e, portanto, realizar a declaração de um propósito. Refiro-me àquelas do tipo: "Vinte centímetros chegou!", "Essa aí chegou mais doida de Londrina!", "Chegou a vagabunda!”, "Um metro está aqui!”

Cada uma destas locuçôes são expressôes com força ilocucionária. Austin (2003 [1962], p.180) opina que até em seu mais mínimo aspecto, enunciar algo é realizar um ato ilocucionário, como, por exemplo, prevenir ou declarar. Ao mesmo tempo, o fato de enunciar pode ser uma expressão constatativa da mesma maneira que uma expressão do tipo "o gato está sobre a almofada" pode ser verdadeira ou falsa.

Assim, o enunciado "Vinte centímetros chegou!" é constatativo na medida em que 
pode ser verdadeiro ou falso; pode ser mentira que o homem que o disse tenha um pênis de vinte centímetros. Ainda sendo constatativo tem força ilocucionária porque tem um efeito que consiste em provocar a compreensão de seu significado.

Da mesma forma, dizer "Vinte centímetros chegou!" dentro do dark room é um enunciado performativo porque a expressão é produzida sob certas circunstâncias apropriadas em um contexto social que admite sua enunciação. Se o enunciado fosse dito dentro de uma igreja, por exemplo, náo deixaria de ser performativo, simplesmente estaria exposto a ser um infortúnio que Grimes (1996) chamou de Nonplay.

As palavras mencionadas, que rompem o silêncio do dark room, são performativas porque são explicitamente uma declaração. Quem as disse não só leva a cabo o ato de declarar, mas também pode despertar efeitos em quem as escuta. Sob este ponto de vista, não só dizem algo, mas afirmam que fazem algo: podem despertar o interesse sexual em quem escuta a mensagem ou podem simplesmente ser tomadas como uma brincadeira.

Outro tipo de expressôes verbais tem lugar no dark room, como por exemplo: "chupa aî", "quer chupar?", "estou a fim de comer", "você dá?", "gostoso". Perguntar a alguém no contexto do dark room (e em geral no contexto da pegação) "você dá?" ou "quer chupar?" são atos performativos com força ilocucionária cuja perlocução pode dar-se por meios verbais ou gestuais. Já o efeito que a pergunta suscita em quem a recebe, depende, em grande medida, da organização das relações sociais. Neste sentido, "aceitar chupar", seja mediante a emissão de um sim, mediante um gesto ou mediante o ato de começar a chupar, permite a disposição dos papéis que compóem o intercurso sexual.

Ser quem faz sexo oral em uma situaçáo de pegação pública pode significar também ser quem "dá", levando em consideraçấo que, para muitos, neste contexto, aceder a ser o primeiro em fazer sexo oral significa que é também quem mais disposto estaria a permitir ser penetrado. Assim, da resposta que o receptor dará a essa pergunta (seja negativa ou positiva) dependerá a forma como pode chegar a ser visto ou interpretado no contexto ritual e, desta maneira, pode determinar as formas de sua participaçáo.

Por outro lado, expressōes como "chupa aî" têm o mesmo efeito de "fecha a porta". Estes enunciados ordenam (ou sugerem) a execução de um ato e nisso consiste sua força ilocucionária. A expressão "estou a fim de comer" no contexto do dark room mais que a simples descrição de um desejo, anuncia a intenção de converter esse desejo em um ato.

Seguindo a caracterização tríplice dos atos de fala como os descreve Austin, poderia se dizer que na expressão "chupa aî" o ato locucionário consiste na produção dessas duas palavras, o ilocucionário consiste em que se deu uma ordem ou uma sugestão e o perlocucionário terá sido que o outro a recebeu como uma graça, um convite ou uma ofensa, dependendo da relação que exista entre eles, do contexto social da situação e dos estados emocionais de quem a vive.

Outras expressóes verbais ou locuçôes compostas por palavras chulas que não mencionei neste artigo, mas que fazem parte da pegação, parecem fazer muito mais sentido em uma interação cujo contexto da situação esta caracterizado pelo anonimato, a escuridáo, o desconhecimento do outro e a carência de afetos ou sentimentos para esse outro desconhecido.

\section{Consideraçóes finais}

Para finalizar, desejo enfatizar como os gestuais, as localizaçóes e deslocamentos pelo espaço físico no dark room posicionam os sujeitos 
DARK ROOM AQUI: UM RITUAL DE ESCURIDÃO E SILÊNCIO | I I I

nas relaçôes face a face e estruturam as formas rituais. Os gestos falam, substituem as palavras, constroem o silêncio, seu "poder mágico", neste contexto ritual, consiste em organizar o acaso, são dispositivos que dispóem e arranjam as interaçôes. Por sua vez, os gestos proporcionam informação acerca do indivíduo que os exerce. No dark room, os gestos conseguem posicionar os sujeitos e aparelhar as normas de participação ritual, conseguem, inclusive, criar distinçôes, contextuais e negociáveis, dos atores sociais entre si.

\section{Dark Room here: a ritual of obscurity and silence}

abstract Among the several urban spaces designed for casual sexual encounters, this paper focuses on the structure of the ritual of interaction in the dark room of a nightclub frequented by men who seek homoerotic practices. I propose a use of J. L. Austin's theory of speech acts in a context where the performative acts are gestures, movements, and the position in the space, among other corporal signs, which not only say, but also do things. How to do things without words? How to do ethnography in silence? What do gestures say? How can one do things by gestures? What is their "magical" power? Is there an inner energy in gestures, just like in words? This investigation is based on theoretical issues from anthropological studies, which question the pre-eminence of language and sight in ethnographical work, and in the study of the ways groups organize their own experiences.

keywords Ritual anthropology. Body. Ethnography. Performative acts. Silence.

\section{Referências bibliográficas}

AUSTIN, John Langshaw. Cómo hacer cosas con palabras. Buenos Aires: Editora Paidós, 2003 [1962]. 218 p.
FINNEGAN, Ruth. How to do things with words: performative utterances among the Limba of Sierra Leone. Man, New Series, Royal anthropological Institute of Great Britain and Ireland, v. 4, n. 4, p. 537-552, 1969.

GARDNER, D. S. Performativity in ritual: The Mianmin case. Man, New Series, Royal anthropological Institute of Great Britain and Ireland, v. 8, n. 2, p. 346-360, 1983.

GRIMES, Ronald. Ritual criticism and the infelicitous performances. In: GRIMES, Ronald (Org.). Readings in ritual studies. New Jersey: Prentice Hall, 1996, p. 279-292.

HERZFELD, Michael. The unspeakable in pursuit of the ineffable: representations of untranslatability in ethnographic discourse. In: RUBEL, P.; ROSMAN, A. (Org.). Translating cultures: perspectives on translation and anthropology. Oxford, New York: Berg, p. 109133, 2003.

JAKOBSON, R. Essais de Linguistique Generale I. Paris: Editions de Minuit, Arguments, 1968 [1960]. 257 p.

LEACH, Edmund. Ritualization in man. In: HUGHJONES, S.; LALDLAW, J. (Org.). The essential Edmund Leach I. New York: Yale University Press, 2000 [1966], 2 v., p. 158-165.

MALINOWSKI, Bronislaw. O significado do significado: um estudo da influência da linguagem sobre o pensamento e sobre a ciência do simbolismo. Rio de Janeiro: Zahar Editor, 1972 [1930]. 349 p.

Coral gardens and their magic: a study of the methods of tilling the soil of agricultural rites in the Trobiand Islands. London: George Allen \& Unwin Ltda, 1935. 2 v. [s. $\left.{ }^{2}\right]$

MAUSS, Marcel. Ensaio sobre a dádiva: forma e razão da troca nas sociedades arcaicas. In: Sociologia e antropologia. São Paulo: Editora Pedagógica e Universitária, 1974, v. 2, p. 37-184.

PERLONGHER, Nestor. O negócio do michê: prostituiçāo viril em São Paulo. São Paulo: Brasiliense, 1987. 275 p.

RIOS, Luis Felipe. O feitiço de Exú: Um estudo comparativo sobre parcerias e práticas homossexuais entre homens jovens candomblesistas elou integrantes da comunidade entendida do Rio de Janeiro. 2004. 330 f. Tese (Doutorado) - Instituto de Medicina Social, Universidade Estadual do Rio de Janeiro. 2004.

SAUSSURE, Ferdinand de. Cours de Linguistique Générale. Paris: Editions Payot, 1994 [1916]. 520 p.

STOLLER, Paul. Sound and things: pulsations of power in Songhay. In: LADERMAN, C.; ROSEMAN, M. 
I I 2 María Elvira Díaz Benítez

(Org.). The performance of healing. New York, London: Routledge, p. 161-182, 1966.

TAMBIAH, Stanley Jeyaraja. The magical power of words. Man: The Journal of the Royal Anthropological Institute, v. 3, n. 2, 1968, p.175-208.

Culture, thought and social action: an anthropological perspective. Cambridge: Harvard University Press, $1985.411 \mathrm{p}$.

\section{Notas}

Esta etnografia foi realizada em uma boate de socialização de homens que exercem práti- cas homoeróticas, no centro do Rio de Janeiro, na qual interagem pessoas diversas em relação à cor da pele, classe, performances de gênero e idade.

\section{Agradecimentos}

Sou grata a Antonádia Borges e Bruno Gomes da Rosa pelas contribuiçóes conceituais na elaboração deste artigo. A Rodrigo Fernandes, Tatiana Siciliano e Camilo Braz pela cuidadosa revisão gramatical da língua portuguesa.

\section{autor María Elvira Díaz Benítez}

Doutoranda em Antropologia Social/MN-UFRJ

Recebido em 31/03/2007

Aceito para publicação em 28/11/2007 